\title{
Effects of PBL Model and Reading Interest towards Explanatory Text Writing Skill
}

\author{
Yesi Delviawati ${ }^{1}$ Agustina $^{2}$, Irfani Basri ${ }^{3}$ \\ \{yesidelviawati17@gmail.com ${ }^{1}$, tien_agustina08@yahoo.com ${ }^{2}$, irfanibasri@ fbs.unp.ac.id ${ }^{3}$ \} \\ ${ }^{1,2,3}$ Faculty of Language and Art, Padang State University, Padang, Indonesia
}

\begin{abstract}
This Research about effect of PBL learning model, and high and low reading interest towards explanation text writing skill of students class VIII SMP N 1 Sungai Geringging.Type of this research is quantitative research with factorial experimental design. Population amount 178 of 8th grade, sample of 60 students. Data collection, namely the instrument of reading interest questionnaire and the test instrument of explanatory text skills performance. Analyzing and discussing data is done by using descriptively-analysis of experimental research.The results can be concluded. First, students' explanatory text writing skills taught using PBL models are higher than students taught using conventional methods. Second, the students' explanatory text writing skills are high in reading interest, higher than students who have low reading interest. Third, there is no interaction between PBL learning models and conventional learning methods with students' interest in reading (high and low) in influencing the explanatory text writing skills.
\end{abstract}

Keywords : effect PBL, reading interest, explanatory text

\section{Introduction}

Writing is a skill that must be mastered by students, but writing skills of students are still inadequate. It is based on a research named Programe For International Student Asessment (PISA). According to this research, the literacy culture of Indonesian people in 2012 was still low compared to other countries, where from 65 countries which have been researched, Indonesia ranked 64th. Thus, the literacy culture of Indonesian was ranked as the second lowest compared to other countries [7]. Students who are aware of their ability to write will develop their potential to the maximum extent possible. It means that through writing, it will make it easier for them to expose all of their potential [9]. Therefore, students must develop their writing skills as well as possible. Correspondingly, "The Student who develops strong writing skills at an early age acquires a valuable tool for learning, communication, self-expression, and helping them succeed in school and society [2]. It means that students who develop strong writing skills at an early age acquire valuable tools for learning, communicating, expressing themselves, helping them succeed in school and in the community. The research about writing skills have been conducted in various countries such as Portugal [12] and Australia by [3]. According to the result of this research, writing skills must be taught at all levels of education. Therefore, 
students 'writing skills must be improved by using various ways to improve students' writing skills.

One of the writing skills learned at the SMP/MTs level is writing explanatory texts on the 4th Core Competency (KI), on the 4.9th Basic Competence (KD), and on the 4.10th Basic Competence (KD). Explanation text is a text that contains an explanation of the process of the occurrence of phenomena or events, both natural, social, and cultural phenomena. Explanation is a text which tells processes relating to the formation of natural, social, scientific, and cultural phenomena. It means that explanatory texts are texts which tell the process related to the formation of natural, social, scientific and cultural phenomena [1]. Reality at school, writing explanatory text learning is still far from the expectations. Students get in trouble with the process of writing explanatory text learning. The ability of students in writing explanatory texts is still far from expectations, where the obstacles are these students are less motivated in writing, written texts are still less logical, students find it difficult to find ideas and develop those ones. Students weaknesses in writing explanatory texts are found in writing the initial statement, then sequencing events systematically, and students' interpretation of the phenomena they write. The constraints of students in writing explanatory texts are related to the structure of the explanatory texts, the use of EBI (Indonesian Language Spelling), and the use of effective sentences, so that writing explanatory text of students are not qualified yet [10]. Same as this research mentioned that there are weaknesses and shortcomings of students in writing explanatory texts. Fundamental deficiencies for students are in the systematic explanatory text structure, improper use of spelling, and linguistic elements that also influence the explanatory text, so text written by students is still far from perfection [11].

From the result of research and observation in the field, learning process which has been applied rarely use learning models that match with materials and student needs in learning process, applying a static learning method is considered not to increase student attention in learning, so the learning process that goes on is a little boring and monotonous. The most commonly applied method is the lecture and question and answer method because it is very easy to be applied and does not require a long time.

Based on the the problems that have been explained above, the immediate solution is needed. One of them is using a much more interesting learning model. The intended learning model is Problem Based Learning (PBL) model. PBL model is expected to make students more active, creative, innovative, and can enhance new knowledge for students.

"Problem Based Learning is one of the innovative learning models that can provide active learning conditions for students. This learning model is conducted by providing stimuli in the form of problems and then, students are expected to solve those problems in order to increase student skills in achieving learning material" [5].

The procedures that can be applied in the implementation of PBL model according "The PBL Process included the following stages: defining the problem, known, and unknown: determining possible solutions collecting and analizing data: the result of analysis and feedback". In other words, the PBL process goes through several stages: defining the problem, needed, known and unknown: determining possible solutions by collecting data analysis: results and analysis.

The next research is about PBL model "Problem Based Learning to Improve Student's Grammar Competence". The results of her research explained that the use of the PBL model increased the ability of learning grammar and grammar of English student. The effectiveness of 
the application of PBL model has a very good impact on student learning outcomes [13]. Application of PBL models to student learning outcomes increases than usual. Based on this research, it is clear that the PBL model is very effectively used as a model that gives good results in a variety of subjects [8].

On the other hand, student learning outcomes are still below the Minimum Completeness Criteria (KKM) which is expected to reach $85 \%$. However, based on the number of students per class, namely students of class VIII, whose grades are completed according to the criteria, only 6 and the rest of them failed and do remedial. In one of the examples of writing found some errors which should be in terms of content must be logical, systematic and communicative, but in the writing of these students found many misuse of language elements in students' explanatory texts. Based on the work of eighth grade students who are not competent in writing explanatory texts, the researchers tried to apply the PBL learning model.

Based on the results of student work that has been analyzed in the form of explanatory text class VIII, the researcher tries to apply the PBL learning model. Researcher interest in choosing the PBL model because seeing in the PBL learning process students are asked individually or in groups to analyze an existing problem in the environment. This is in accordance with the learning material for explanatory texts, namely writing activities that are in accordance with the process of occurrence of an event. It is recommended that the application of the PBL model in writing lesson is students can provide quality writing in accordance with the facts they find in the field and these students can be more confident in writing their responses as well.

\section{Research Methods}

Type of this research is quantitative research, it is processing data (scores) with numbers. The data (score) is derived from a questionnaire of reading interest and explanatory texts of class VIII students of SMP N 1 Sungai Geringging. This research uses squasy experiment method. The research design is factorial design $(2 \times 2)$.

The population in this research are students of class VIII SMP N 1 Sungai Geringging in the 2018/2019 academic year consisting of 6 classes (Class VIII 1 to VIII 6) with a total number of students are 178. Because the population is more than 100 people, it means that the sample is drawn using a purposive sampling technique for more detailed sampling as follows. (a) Conduct a normality test to find out whether the population is normally distributed or not. The test used is the Liliefors test. (b) Conduct a variance homogeneity test is carried out to determine whether the population has homogeneous variance or not. The test used is the Bartlett test for more accurate data. (c) Determine the control class and the experimental class. Based on the data in the table above, the sample chosen is class VIII-4 and VIII-6 because of the following points. First, the two classes are normally distributed, the average value is not much different, compared to other classes. Secondly, in this class, students' ability to write is still low and not yet in accordance with KKM. Third, students' interest in reading is still lacking. Fourth, these two classes were suggested by the subject's teacher, Ibu Patrisna, S.Pd, to examine the students' ability to write explanatory texts because they had results that were not much different.

Data collection instruments in this research are reading interest questionnaire sheets to find out students 'interest in reading and performance tests to find out students' explanatory text writing skills.

The questionnaire data analysis process is as follows. (1) read the questionnaire filled out by students. (2) identify the questionnaire whether it has been filled in as a whole. (3) give a score on the student questionnaire. (4) summing the overall score. (5) sort scores from low to 
high scores. (6) divide students' interest in reading into two groups, where $27 \%$ for upper class and lower class groups.

The process of analyzing data on explanatory text writing skills is as follows. (1) read the students overall explanatory text whether the data in accordance with research data. (2) give a score to the writing of students in accordance with the assessment indicators. (3) change the score based on the PAP (Benchmark Reference Assessment), convert the score into a value by using a percentage formula to determine the level of mastery of explanatory text writing skills. (4) the results of calculations with the formula are transformed on the scale used. (5) describes the distribution of explanatory text writing skills tests. (6) displays data in the form of bar charts. (7) hypothesis testing

\section{Discussion}

\section{Students' Skilled Text Exploration Skills that are Taught by Using PBL Models and Conventional Learning Methods}

The results of testing the first hypothesis, showed that the overall results of students' explanatory text writing skills using PBL models are higher than the students' explanatory text writing skills taught using conventional learning methods. The value obtained by students in the experimental class is higher than the value obtained by students in the control class.

Other than that, there are average differences between the experimental class and the control class. The average explanatory text writing skills of the experimental class is higher than the control class. This is due to the effect of the treatment given on the experimental class. The experimental class had an average of 84.97 with 30 students. Furthermore, the control class obtained an average value of 74.26 with 30 students.

PBL learning model is a model that encourages students to think systematically, dare to face problems, so students are able to solve or solve problems, both in their personal lives, and in groups in a way looking for data so that it can draw a conclusion [4].

It can be concluded that the theory in chapter two can be true in this research. In the experimental class showed that the explanation of writing explanatory text skills increased.

\section{Explanation Text Writing Skills of Students Who Have High Reading Interest with Explanation Text Writing Skills of Students Who Have Low Reading Interest}

The results of the second hypothesis testing showed that the explanatory text writing skills of students who had high reading interest with students who had low reading interest. In addition, the results of explanatory text writing skills of students who have high reading interest, are higher than students who have low reading interest.

Based on this explanation, it can be concluded that the interest in reading in writing, especially writing explanatory texts is very important. Students who have high reading interest will find it easier to write explanatory texts. Vice versa, students with low reading interest will find it more difficult to write explanatory texts. 


\section{Interaction between Interest in Reading and PBL Model in Influencing Explanation Text Writing Skills}

Interaction occurs when the effect of one factor depends on other factors influencing something [6]. This means that each factor between the PBL model and reading interest are interdependent in influencing students' explanatory text writing skills.

There is no interaction between the PBL model and reading interest. This happens at both levels of interest in reading, both high and low, which are both taught by using the PBL learning model. The average value of students' explanatory text writing skills has high and low reading interest in the experimental class is higher than students have high reading interest in the control class as shown in the following interaction graph.

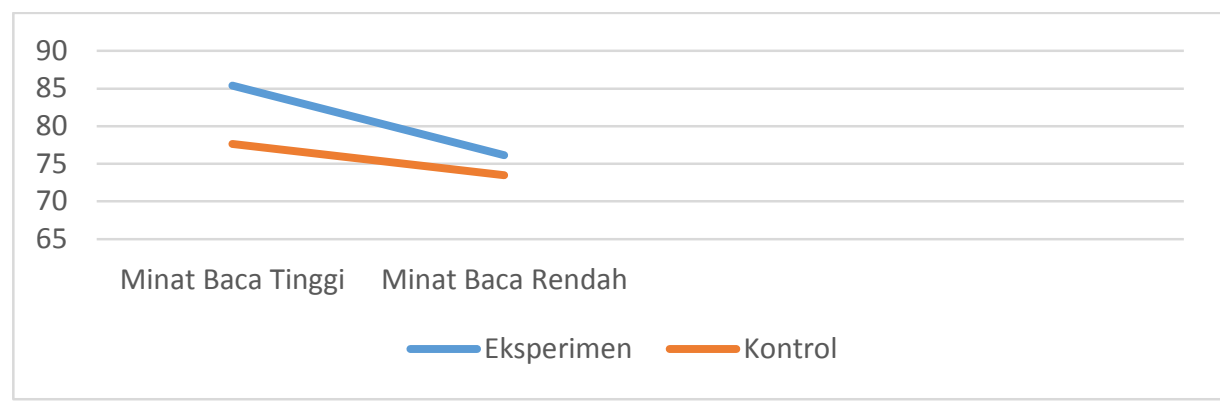

\section{Figure. Interaction Diagram of PBL Model and Reading Interest in Explanatory Text Writing Skills}

Based on Figure, it is seen that the average difference in the experimental class and the control class is that students who have high reading interest taught with the PBL model have an average of 85.38 while students who have high reading interest who are taught by conventional methods have average average of 77.63. Students who have low reading interest in the experimental class taught with PBL models amounted to 76.13, while students who had low reading interest in the control class taught by conventional methods were 73.5.

There is no interaction of each factor of the PBL model and reading interest that affect students' explanatory texts. Nonetheless, the PBL model has proven to be more effectively applied to two levels of students who have high reading interest and low reading interest.

\section{Conclusions and Suggestions}

Based on data analysis and discussion, it is known that the application of the PBL model can influence the results of explanatory text writing. First, the results of students' explanatory text writing skills taught with PBL models are higher than conventional methods. This is caused by the treatment used in the learning model and has its own advantages, so students are more active and expressive in writing.

Secondly, there are differences in the results of explanatory text writing skills of students who have high reading interest and students who have low reading interest. The results of explanatory text writing skills of students who have high reading interest, are higher than students who have low reading interest. This proves that having a high interest in reading will 
make it easier for students to write, the number of readings that will provide insight and views regarding ideas or ideas that will be written. and increase vocabulary obtained from reading activities.

Third, overall in this study there was no interaction between the PBL model and the interest in reading in influencing the learning outcomes of students' explanatory text writing skills. This is caused by students who have the ability to write may not necessarily have a high interest in reading, but if you have a high interest in reading will make it easier for students to write. The PBL model can still be applied to students who have low reading interest.

The above shows that without having an interest in reading, PBL models can still influence the learning outcomes of students' explanatory text writing skills. Furthermore, students who have high reading interest and low reading interest can be taught with the PBL model. Thus the use of PBL models in writing explanatory texts is very good to be applied to learning writing materials, one of which is to write explanatory texts. It is hoped that the PBL model can be well developed, so that it has a far more impact.

\section{References}

[1] A, A. M. dan K.: Text types in English. australia: Macmillan Education. pp. 59 (1997).

[2] Graham, S., Bollinger, A., Olson, C. B., D’Aoust, C., McCutchen, D., \& Olinghouse, N.: Teaching Elementari School Students to be Effective Writers: a Practice Guide. Vol. 40, pp 5. Journal Internasional (2012)

[3] H, W.: Reading and Writing in Southeast Asean Languages". Procedia - Social and Behavioral. Vol. 9, pp. 7. Journal Internasional (2013).

[4] Hariyanto, W.: Pembelajaran aktif. Bandung. pp. 367 (2012).

[5] Himah EF.: Penerapan model PBL disetai metode pictorial ridlle dalam pembelajaran fisika. Vol. 4, pp. 5. Jurnal Pembelajaran (2015).

[6] Irianto.: statistik pendidikan. gajah mada: univercity press. pp. 225 (2004).

[7] Kompasiana. (2014). generasi miskin membaca. Retrieved from http://kompasiana.com

[8] Masyara.: The Effectiveness of Problem Based Learning Model On Student Learning. Vol. 4, pp 7. Journal Internasional (2016).

[9] Mosapour. (2011). A. Study On Strategi Instruction and EFL Learners' Writing Skil. Vol. 1, pp. 2. Journal Internasional (2011).

[10] Nadriati.: Pengaruh model pembelajaran discovery learning dengan mempertimbangkan motivasi belajar terhadap keterampilan menulis teks eksplanasinasi. Universitas Negeri Padang. pp. 5 (2017).

[11] Rizky.: Hugungan minat baca dan motifasi belajar dengan keterampilan menulis teks eksplanasi siswa kelas VIII SMP Negeri 13 Padang. Universitas Negeri Padang. pp. 4 (2014).

[12] S, F. A. (2012): Writing to Learn Writing Skils- a Case Study”. European of Engineering Education. Vol. 37, pp. 2. Journal Internasional (2013).

[13] Zuhriyah M.: Problem Based Learning to Improve Students' Grammar Competence. Vol. 10,pp. 1. Jurnal Pembelajaran (2017). 